\title{
Synthesis and Characterization of Nuclear RNA induced by Radix Ginseng Extract in Rat Liver ${ }^{1)}$
}

\author{
Hikokichi Oura, Susumu Hiai, and Hachiro Seno \\ Department of Biochemistry, Drug Research Institute, Faculty \\ of Pharmaceutical Science, Toyama University')
}

(Received January 5, 1971)

\begin{abstract}
The in vivo administration of a fraction obtained by partial purification of radix ginseng extract stimulated the incorporation rate of labeled precursors into nuclear RNA, and a maximum increase was shown at $4 \mathrm{hr}$ after a single dose intraperitoneal injection and the rate returned almost to the control level $24 \mathrm{hr}$ after treatment in a rat. However, the RNA content of nuclei isolated from each interval after treatment is the same in the RNA to DNA ratio as in the control animals. The sedimentation profile by sucrose density gradient of rapidly labled nuclear RNA isolated from the liver of a rat treated with fraction 4 showed a stimulation in the $23 \mathrm{~s}$ to $7 \mathrm{~s}$ region which has a peak at 10 s region. Rate of the incorporation of labeled precursors into the interphase RNA rather than the nuclear sap RNA was stimulated significantly by fraction 3 and the base composition of this ${ }^{32} \mathrm{P}$ pulse-labeled RNA showed an intermediate value between the ribosamal and DNA-like RNA. The effect of ginseng extract (fraction 3) on the nuclear DNA synthesis was not observed in the present assay by the incorporation of ${ }^{3} \mathrm{H}$-thymidine in rat liver.
\end{abstract}

In a previous paper, ${ }^{3)}$ we reported that the in vivo administration of an extract from the root of Panax ginleng C.A. MEYer significantly increased the incorporation rates of labeled precursor into rapidly snythesized liver nuclear RNA at $4 \mathrm{hr}$ and into cytoplasmic polysomal RNA at $5.5-6.0 \mathrm{hr}$ after a single dose intraperitoneal injection in a rat, and that this stimulating factor was obtained by partial purification. Also, we reported that these incorporation rates were directly dependent on the amount of a purified fraction. It was suggested that the synthesis of rapidly labeled RNA in a nucleus was stimulated by ginseng extract, and that this RNA was then transferred to the cytoplasm.

Indeed, several investigators have recently stated that many hormones stimulate the synthesis of rapidly labeled RNA of a nucleus in specific target organs or livers, and hormonal action has been explained as the regulation of protein synthesis. ${ }^{4}$

The present study was undertaken to obtain more information about ginseng extract action for synthesis and characterization of nuclear RNA as follows: (a) Time course of the effect of ginseng extract on the nuclear RNA synthesis, (b) RNA content of isolated nuclei, (c) effect of graded dose of actinomycin D on the nuclear RNA synthesis of ginseng extracttreated liver, (d) sucrose density gradient analysis of pulse-labeled nuclear RNA of treated liver, and (e) effect of ginseng extract on synthesis of the interphase RNA isolated from phenol-treated nuclei.

\section{Material and Method}

Animals_-Male Wistar rats weighing about $100 \mathrm{~g}$ were used for all the experiments. Rats were obtained locally and were fasted for $16-18 \mathrm{hr}$ prior to the experiments.

1) This work was presented at the 86th Annual Meeting of the Pharmaceutical Society of Japan, Sendai, October 1966.

2) Location: 3190 Gofuku, Toyama, 930, Japan.

3) H. Oura, S. Hiai, S. Nakashima, and K. Tsukada, Chem. Pharm. Bull. (Tokyo), 19, 453 (1971).

4) J.R. Tata, "Progress in Nucleic Acid Research and Molecular Biology," Vol. 5, Academic Press, Inc., New York, 1966, p. 191. 
Chemicals-6- ${ }^{14} \mathrm{C}$-Orotic acid $(32.6 \mathrm{mCi} / \mathrm{mm})$ and ${ }^{32} \mathrm{P}$-ortho-phosphote $(54.4 \mathrm{Ci} / \mathrm{mg}$ phosphorus) were obtained from the Radiochemical Centre, England. $5-{ }^{3} \mathrm{H}$-Orotic acid $(5 \mathrm{mCi} / 3.49 \mathrm{mg})$ was the product of New England Nuclear Corp., U.S.A. Actinomycin-D was supplied from the Merck Sharp and Dohme Research Laboratories, U.S.A. All other chemicals used in this study were of analytical or reagent grade and were used without further purification.

Extraction and Partial Purification of Radix Ginseng___Fraction 3 and 4 were prepared from the extract of roots of Panax ginseng C.A. MEYer produced in Kumsan, Korea, as previously described.3) Roots of ginseng were powdered and extracted with $0.05 \mathrm{M}$ Tris- $\mathrm{HCl}$ buffer $(\mathrm{pH} 7.6)$ under stirring for $48 \mathrm{hr}$ in a cold room. The filtrate was brought to $70 \%$ saturation of ammonium sulfate. The precipitate was dissolved in distilled water, dialyzed against running cold water for $48 \mathrm{hr}$ until salt-free, and then the inside solution was lyophilized (fraction 3). Fraction 3 was extracted with $99 \% \mathrm{MeOH}$ on a water bath under refluxing, and $\mathrm{MeOH}$ solution was concentrated. To this residual solution was added 15 volumes of cold ether. The white or slightly yellowish precipitate (fraction 4) was dried overnight in vacuo. Preliminary chemical examination of fraction 3 gave positive Liebermann-Burchard reaction, and it contained about $50 \%$ of hexose by the Tsugita and Akabori's method.s) $\quad$ Preliminary properties of fraction 4 are as follows: $\mathrm{mp} 180-190^{\circ}$; LiebermannBurchard reaction, positive; hexose content, $70-75 \%$.

Separation of Nuclei_- Three rats were used in one group. The purified nuclei were prepared with $2.2 \mathrm{M}$ sucrose, $105000 \times g$ for $1 \mathrm{hr}$ by the procedure described in a previous paper. ${ }^{3)}$

Nuclear RNA Labeling - Fraction 3 or 4 was given to rats intraperitoneally with saline solution. Control rats were treated with an equal volume of saline. At $4 \mathrm{hr}$ after the administration of each fraction, labeled orotic acid was injected intraperitoneally to animals $20 \mathrm{~min}$ prior to killing by decapitation. In the ${ }^{32} \mathrm{P}$-ortho-phosphate experiments, animals were given each fraction, saline solution of ${ }^{32} \mathrm{P}$-phosphate was administered to rats intraperitoneally $4 \mathrm{hr}$ later, and the animals were killed $1 \mathrm{hr}$ later by exsanguination after cutting the abdominal aorta under ether anesthesia.

Assay of Specific Radioactivity of Nuclear RNA-Nuclear RNA was determined by the Dische and Borenfreund's method. ${ }^{6}$ The radioactivity was determined by the Bray's solution ${ }^{7}$ as described in a previous paper. ${ }^{3)}$

Assay of Specific Radioactivity of Nuclear DNA_- The purified nuclear suspension was treated with cold $0.6 \mathrm{~N}^{-\mathrm{HClO}_{4}}$. To the precipitate, $0.5 \mathrm{~N} \mathrm{HClO}_{4}$ was added and the sample was digested at $70^{\circ}$ for $20 \mathrm{~min}$. The extract was assayed by Burton's method $\left.{ }^{8}\right)$ for DNA determination. Also, the extract was neutralized with cold $1.0 \mathrm{~N} \mathrm{KOH}$ and centrifuged. The specific radioactivity (cpm/mg DNA) was determined by aliquots of this supernatant in the Bray's solution?) for radioassay.

Isolation of Nuclear RNA at $25^{\circ}$ — The purified nuclear pellet derived from 9-10 $\mathrm{g}$ of the liver was

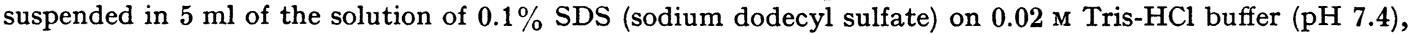
at $0^{\circ}$ for $5 \mathrm{~min}$, followed by treatment for $25 \mathrm{~min}$ at $25^{\circ}$ with an equal volume of water-saturated redistilled phenol containing $0.1 \%$ 8-hydroxyquinoline. ${ }^{9}$ ) The aqueous phase was made $0.2 \mathrm{M}$ potassium acetate, treated twice for 10 min with 0.5 volume of the phenol solution, RNA was precipitated by the addition of 0.1 volume of $0.1 \mathrm{M} \mathrm{MgCl}_{2}$ and 2.5 volumes of $95 \% \mathrm{EtOH}$, and allowed to stand overnight at $-20^{\circ}$.

The precipitated RNA was dissolved in $0.005 \mathrm{M}$ Tris- $\mathrm{HCl}(\mathrm{pH} 7.6)$, the aqueous phase was extracted three times with 2 volumes of ether, and flushed with a stream of nitrogen. Preparations of nuclear RNA from control and ginseng extract-treated rats were isolated simultaneously, and both contained less than $1 \%$ DNA by determination with Burton's method. ${ }^{8)}$ The radioactivity of the nuclear RNA was determined by the procedure of Staehelin, et al.,10) as described in a previous paper. ${ }^{3)}$

Isolation of Interphase RNA-Isolation of interphase nuclear RNA from phenol-treated nuclei was carried out by the modified method of Georgiev, et al. ${ }^{11)}$ as follows. The nuclear pellet derived from $9-10 \mathrm{~g}$ of the liver was suspended in $5 \mathrm{ml}$ of $0.14 \mathrm{M} \mathrm{NaCl}$ in $0.01 \mathrm{M}$ acetate buffer ( $\mathrm{pH} 5.6$ ), followed by treatment for $10 \mathrm{~min}$ at $4^{\circ}$ with an equal volume of $80 \%$ aqueous phenol. After centrifugation at $13000 \times g$ for $5 \mathrm{~min}$ at $4^{\circ}$, the aqueous and interphase layers were isolated carefully by a pipette.

The aqueous layer was made $0.5 \%$ SDS and shaken with $80 \%$ phenol at $4^{\circ}$ for 5 min. RNA was precipitated by the addition of 2.5 volumes of $\mathrm{EtOH}$ and allowed to stand overnight at $-20^{\circ}$ as previously described (cold extracted RNA).

The interphase was collected and consecutively extracted three times with $4 \mathrm{ml}$ of $0.14 \mathrm{M} \mathrm{NaCl}$ in $0.01 \mathrm{M}$ acetate buffer ( $\mathrm{pH} \mathrm{5.6)}-80 \%$ phenol for $10 \mathrm{~min}$ at $4^{\circ}$. Finally, the interphase was shaken with $0.5 \%$ SDS$0.14 \mathrm{M} \mathrm{NaCl}-0.01 \mathrm{M}$ sodium acetate buffer $(\mathrm{pH} \mathrm{5.6})$ at $55^{\circ}$ for $5 \mathrm{~min}$. RNA was precipitated by the addition of $\mathrm{EtOH}$ by the same procedure as described above (interphase RNA or hot extracted RNA).

5) A. Tsugita and S. Akabori, J. Biochem. (Tokyo), 46, 695 (1959).

6) Z. Dische and E. Borenfreund, Biochim. Biophys. Acta, 23, 639 (1957).

7) G.A. Bray, Anal. Biochem., 1, 279 (1960).

8) K. Burton, Biochem. J., 61, 473 (1955).

9) M.B. Sporn and W. Dingman, Biochim. Biophys. Acta, 68, 387 (1963).

10) T. Staehelin, F.O. Wettstein, H. Oura, and H. Noll, Nature, 201, 264 (1964).

11) G.P. Georgiev, O.P. Samarina, M.I. Lerman, M.N. Smirnov, and A.N. Severtzov, Nature, 200, 1291 (1963). 
Zone Centrifugation of Nuclear RNA — Nuclear RNA was analyzed by the sedimentation coefficints with $0.5-1.0 \mathrm{~m}$ linear sucrose density gradient containing $0.005 \mathrm{M}$ Tris- $\mathrm{HCl}, \mathrm{pH} 7.2$ (see Ref. 10). Centrifugation was carried out in a Hitachi RPS-25 rotor at $24000 \mathrm{rpm}$ for $40 \mathrm{hr}$ at $2-4^{\circ}$. The bottom of the plastic tube was punctured with a hypodermic needle and absorbance was analyzed continuously in a flowthrough cuvette (at $254 \mathrm{~m} \mu$ by Uvicord) attached to a strip chart recorder (New York Photo Volt Co.). A constant-flow rate was maintained with a precision pump. Fractions of $1.25 \mathrm{ml}$ each were collected and radioactivity of each fraction was precipitated with $\mathrm{HClO}_{4}$, washed, and then assayed by hyamine-toluene scintillation liquid, as described in a previous paper. ${ }^{3)}$ Sedimentation coefficients were determined essentially by the procedure of Staehelin, et al. ${ }^{10}$ )

Base Composition Analysis- The interphase RNA (hot extracted RNA) was charged into methylated albumin-kieselguhr (MAK) column and eluted with $0.1 \mathrm{M} \mathrm{NaCl}-0.05 \mathrm{~m}$ phosphate buffer ( $\mathrm{pH} 7.6$ ) in order to ensure removal of contaminating inorganic ${ }^{32} \mathrm{P}$ by the procedure of Kimura, et al. ${ }^{12}$ ) Finally, RNA was eluted with $0.5 \%$ SDS and subjected to alkaline hydrolysis with $0.4 \mathrm{~N} \mathrm{KOH}$ for $18 \mathrm{hr}$ at $37^{\circ}$. The ribonucleotides were separated according to the method of Davidson and Smellie. ${ }^{13}$ Base ratios for labeled interphase RNA were determined by distribution of ${ }^{32} \mathrm{P}$.

\section{Result}

\section{Time Course of the Effect of Ginseng Extract on the Nuclear RNA Synthesis}

Previous experiments ${ }^{3)}$ demonstrated that treatment with fraction 3 isolated from ginseng roots increased the incorporation rate of the rapidly labeled nuclear RNA by $61 \%$ over that of the control animals after $4 \mathrm{hr}$. To obtain further evidence on the action of ginseng extract

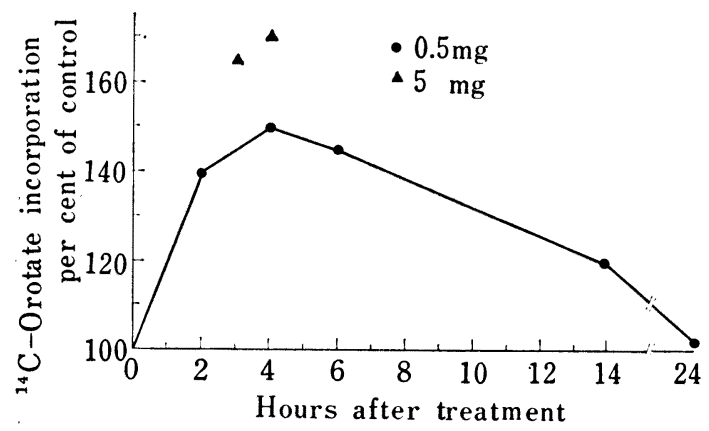

Fig. 1. Time Course of Effect of Fraction $3 \mathrm{tr}$ eatment on the Incorporation of ${ }^{14} \mathrm{C}$-Orotic Acid into Liver Nuclear RNA

Fraction $3(0.5 \mathrm{mg})$ was administered intraperitoneally to rats and ${ }^{14} \mathrm{C}$-orotic acid $(2.5 \mu \mathrm{Ci} / \mathrm{rat})$ was injected intraperitoneally $20 \mathrm{~min}$ prior to killing the animals by decapitation. The specific radioactivity (cpm/mg nuclear RNA) of nuclear RNA isolated at the designated time was assayed as descrbibed in Methods. The control values are $37000 \pm 1950 \mathrm{cpm} / \mathrm{mg}$ RNA. For each period of time tested for fraction 3 action, separate control experiments were performed. The control values given here at a zero $\mathrm{hr}$ for specific nuclear RNA activity represent respectively the mean for 5 control groups (i.e., five for each time period of fraction 3 action tested). The data are expressed as percentage of control value. Three rat livers were pooled for each experimental or control group. $\mathrm{mg}, \Delta: 5.0 \mathrm{mg}$ of fraction 3

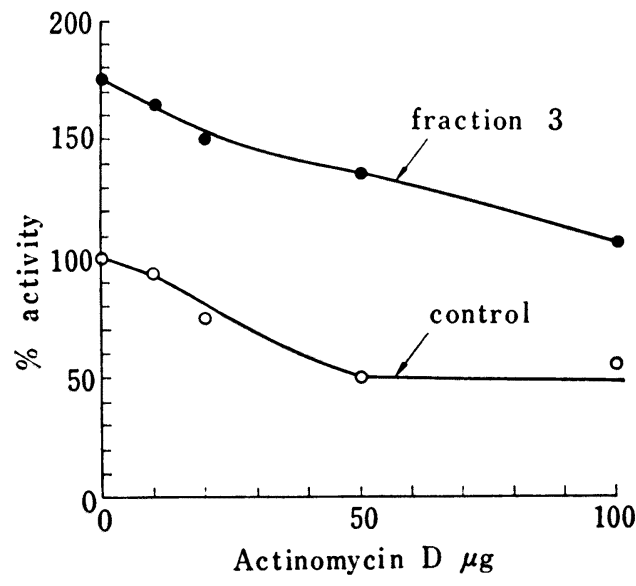

Fig. 2. Inhibitory Effect of Graded Dose of Actinomycin-D on the Incorporation Rate of ${ }^{3} \mathrm{H}$-Orotic Acid into Nuclear RNA induced by Fraction 3

At $4 \mathrm{hr}$ after intraperitoneal administration of actinomycin-D, ${ }^{3} \mathrm{H}$-orotic acid $(7 \mu \mathrm{Ci} / \mathrm{rat})$ was injected intraperitoneally $20 \mathrm{~min}$ prior to killing the animals by decapitation. The specific radioactivity of nuclear RNA was assayed as described in Methods. For experimets involving actinomycin-D and fraction 3, the experiments were carried out as follows: at $4 \mathrm{hr}$ after simultaneous intraperitoneal administration of actinomycin-D and ${ }^{2} \mathrm{H}$-orotic acid $(7 \mu \mathrm{Ci} / \mathrm{rat})$ was injected intraperitoneally $20 \mathrm{~min}$ prior to killing the animals by decapitation. Fraction $3(5 \mathrm{mg})$ was used for all the experiments. The control values are $35450 \pm 2800 \mathrm{cpm} / \mathrm{mg}$ nuclear RNA, and this value represents the mean for 4 control groups. Three rat livers were pooled for each experimental or control group.

12) K. Kimura, J. Tomoda, and A. Sibatani, Biochim. Biophys. Acta, 108, 540 (1965).

13) J.N. Davidson and R.N. Smellie, Biochem. J., 52, 594 (1952). 
in nuclear RNA synthesis, the incorporation of ${ }^{14} \mathrm{C}$-orotic acid into nuclear RNA was assayed at $2,4,6,14$, and $24 \mathrm{hr}$ after pretreatment with fraction 3.

Normal and fraction 3 treated rats were injected with ${ }^{14} \mathrm{C}$-orotic acid, the animals were killed 20 min later, and the nuclei were isolated. The specific radioactivity of nuclear RNA was determined. Fig. 1 shows the effect of fraction 3 pretreatment on the incorporation of ${ }^{14} \mathrm{C}$-orotic acid into nuclear RNA. From the data presented in Fig. 1, it was evident that the greatest specific radioactivity of nuclear RNA was at $4 \mathrm{hr}$ after treatment, and increased $50 \%$ over the control level by $0.5 \mathrm{mg}$ of fraction 3 . At 2 and $6 \mathrm{hr}$ after pretreatment, there were 40 and $45 \%$ respective increase in the specific radioactivity. On the other hand, at $14 \mathrm{hr}$ after administration of fraction 3, this response showed only a $20 \%$ increase over the control animals and returned almost to the control rate at $24 \mathrm{hr}$ after treatment. In these experiments, administration of $5 \mathrm{mg}$ of fraction 3 showed 65 and $70 \%$ increases at 3 and $4 \mathrm{hr}$, respectively, after treatment over the control level.

\section{RNA Content of Isolated Nuclei}

An accumulation of RNA in the nuclei of fraction 3 treated rats may be expected if fraction 3 increases the rate of nuclear RNA synthesis and does not concomitantly increase the rate of RNA degradation or the transfer of RNA out of the nucleus. However, at 4, 8, 12, and $16 \mathrm{hr}$ after fraction 3 treatment, the RNA content of isolated nuclei was the same ratio as in the controls, and there was no significant increase in the ratio of RNA to DNA (Table I).

TABLE I. Liver Nuclear RNA Content of Control and Fraction 3-Treated Rats

\begin{tabular}{lccc}
\hline Material & $\begin{array}{l}\text { Time after } \\
\text { fraction 3 } \\
\text { treatment (hr) }\end{array}$ & $\begin{array}{l}\text { No. of } \\
\text { rats }\end{array}$ & $\begin{array}{l}\text { Ratio of } \\
\text { RNA/DNA }\end{array}$ \\
\hline Control (saline) & 0 & 6 & 0.21 \\
Fraction 3 & 4 & 6 & 0.18 \\
Fraction 3 & 8 & 6 & 0.21 \\
Fraction 3 & 12 & 6 & 0.22 \\
Fraction 3 & 16 & 6 & 0.21 \\
\hline
\end{tabular}

Five mg of fraction 3 was administered intraperitoneally to each rat. At the designated time after the treatment, purified nuclei were prepared from the animals as described in Methods. DNA and RNA were assayed by the Burton ${ }^{8}$ and Dische ${ }^{6}$ ) methods, respectively.

a) These values show the average of two experimental results.

\section{Effect of Graded Dose of Actinomycin-D on Nuclear RNA Synthesis}

An attempt was made to determine the dose-response relation of actinomycin-D on the fraction 3-stimulated nuclear RNA synthesis. In preliminary experiment, we found that the in vivo administration of Actinomycin-D (250 $\mu \mathrm{g} / \mathrm{rat})$ inhibited $88 \%$ of the incorporation rate of ${ }^{3} \mathrm{H}$-orotic acid into nuclear RNA of control animals at $4 \mathrm{hr}$ after treatment.

In order to obtain the dose-response curve of Actinomycin-D, we assayed the specific radioactivity of nuclear RNA at $4 \mathrm{hr}$ after administration for $20 \mathrm{~min}$ labeling before killing. Further, $5 \mathrm{mg}$ of fraction 3 was administered with graded doses of Actinomycin-D simultaneously, and the specific radioactivity of nuclear RNA was determined as shown in Fig. 2.

The results of these experiments show that the suppressed rates of ${ }^{3} \mathrm{H}$-orotic acid incorporation into nuclear RNA are almost parallel with control and fraction 3 treatment groups. Also the incorporation rate stimulated by fraction 3 was suppressed to the control level (nontreated animals) of $100 \%$ by $100 \mu \mathrm{g}$ of Actinomycin-D at $4 \mathrm{hr}$ after coadministration.

\section{Labeling and Characterization of Nuclear RNA Fraction}

The nuclear RNA was isolated by phenol extraction at $25^{\circ}$ from normal and ginseng extract-treated rat liver as described in Methods. Administration of $5 \mathrm{mg}$ of fraction 3 
or 4 stimulated 78 or $174 \%$ respective increase after $4 \mathrm{hr}$ in the specific radioactivity of nuclear RNA isolated by phenol extraction, over the control levels (Table II).

TABLE II. Effect of ginseng Extract on the Incorporation of Labeled Orottic Acid into Nuclear RNA isolated by Phenol Extraction at $25^{\circ}$

\begin{tabular}{|c|c|c|c|}
\hline Expt. No. & Material & $\begin{array}{l}{ }^{3} \mathrm{H} \text { - or }{ }^{14} \mathrm{C}-\text {-Orotic acid } \\
\text { cpm per absorbance } \\
\text { unit at } 260 \mathrm{~m} \mu \text { of } \\
\text { nuclear RNA }\end{array}$ & $\%$ \\
\hline \multirow[t]{2}{*}{1} & control (saline) & 1228 & 100 \\
\hline & fraction 3 & 2192 & 179 \\
\hline \multirow[t]{2}{*}{2} & control (saline) & 1848 & 100 \\
\hline & fraction 4 & 5072 & 274 \\
\hline
\end{tabular}

At $4 \mathrm{hr}$ after treatment, labeled orotic acid was given intraperitoneally 20 min prior to killing the animals by decapitation. In Expt. 1, fraction $3(5 \mathrm{mg})$ was administered to rats, and ${ }^{2} \mathrm{H}$-orotic acid $(10 \mu \mathrm{Ci})$ was injected per rat. In Expt. 2, fraction $4(5 \mathrm{mg})$ was administered and ${ }^{16}$-C-orotic acid $(4 \mu \mathrm{Ci})$ was injected per rat.

The sedimentation profile by sucrose density gradient centrifugation of this rapidly labeled nuclear RNA is shown in Fig. 3. As reported by many workers ${ }^{11-13)}$ with respect to normal nuclear RNA prepared by a similar extraction method, we observed three peaks of RNA by absorbance which corresponded to $29 \mathrm{~S}, 18 \mathrm{~S}$, and 5 to $6 \mathrm{~S}$ (Svedberg units). The stimulatory effect of ginseng extract on the orotic acid incorporation differed with various RNA fractions in absorbance pattern as shown in Fig. 3B, and was the largest in $10 \mathrm{~S}$ region. This area roughly corresponds to $\mathrm{m}-\mathrm{RNA}$ which was reported to have a greater amount of activity in stimulating the incorporation of amino acids into protein in a cell-free $E$. coli system. ${ }^{14-17}$ )

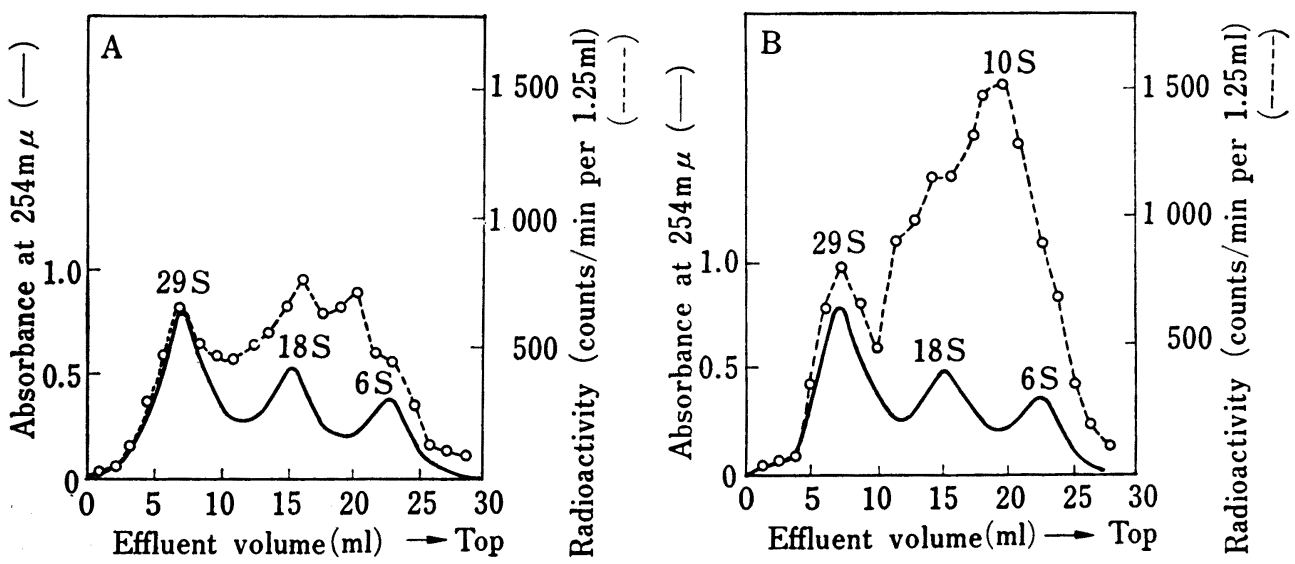

Fig. 3. Sucrose Density Gradient Analysis of Nuclear RNA isolated at $25^{\circ}$ from (A) Normal and (B) Fraction 4-Treated Rat Liver

Fraction 4 (5 mg) was given to rats. At $4 \mathrm{hr}$ after treatment ${ }^{2} \mathrm{H}$-orotic acid $(10 \mu \mathrm{Ci} / \mathrm{rat})$ was injected intraperitoneally $20 \mathrm{~min}$ prior to killing the animals by decapitation. Each nuclear RNA of 10 absorbance untis (at $260 \mathrm{~m} \mu$ ) were layered on a $0.5-1.0 \mathrm{~m}$ linear sucrose gradient.

14) L.A. Loeb and H.V. Gelboin, Proc. Natl. Acad. Sci. U.S., 52, 1219 (1964).

15) A. DiGirolamo, E.C. Henshow, and H.H. Hiatt, J. Mol. Biol., 8, 479 (1964).

16) J.H. Mattaei and M.W. Nirenberg, Proc. Natl. Acad. Sci. U.S., 47, 1580 (1961).

17) F.T. Kenney and F.J. Kull, Proc. Natl. Acad. Sci. U.S., 50, 493 (1963). 


\section{Labeling and Characterization of Interphase RNA Fraction}

Metabolically active RNA is concentrated in the phenol-water interphase gel by a phenol treatment of purified nuclei. ${ }^{11,12,18)}$ Table III shows that administration of $5 \mathrm{mg}$ of fraction 3 increased the specific radioactivity only $24-41 \%$ in the cold extracted (aqueous phase) nuclear RNA, but the nuclear RNA isolated from interphase gel at $55^{\circ}$ (hot extracted RNA) was increased $92-140 \%$ over the control levels. This hot extracted RNA has polydisperse and a broad peak on the sucrose density gradient pattern. ${ }^{19)}$

TABLE III. Effect of Fraction 3 on the Incorporation of ${ }^{32} \mathrm{P}$-Ortho-phosphate into Cold Extracted Nuclear and Interphase (Hot Extracted) RNA

\begin{tabular}{cllll}
\hline \hline Expt. No. & $\begin{array}{l}\text { Condition of } \\
\text { RNA extraction }\end{array}$ & Material & $\begin{array}{l}\text { 32P-Phosphate cpm } \\
\text { per absorbance unit } \\
\text { at 260 m } \mu \text { of } \\
\text { nuclear RNA }\end{array}$ & $\%$ \\
\hline 1 & cold & control (saline) & 32250 & 100 \\
& cold & fraction 3 & 39860 & 124 \\
& hot & control (saline) & 44640 & 100 \\
fraction 3 & control (saline) & 85440 & 192 \\
hot & cold & contron 3 (saline) & 32656 & 100 \\
& cold & fraction 3 & 46000 & 141 \\
& hot & hot & 117120 & 100 \\
& hot & & 240 \\
\hline
\end{tabular}

In Expts. 1 and 2, fraction $3(5 \mathrm{mg})$ was administered to rats, and ${ }^{32} \mathrm{P}$-ortho-phosphate $(3 \mathrm{mCi})$ was injected intraperitoneally per rat.

TABLE IV. Base Composition of the RNA Fraction Obtained from the Interphase of the Rat Liver Nuclei

\begin{tabular}{|c|c|c|c|c|c|}
\hline & \multicolumn{5}{|c|}{ Percentage of total radioactivity in } \\
\hline & $\mathrm{C}$ & A & G & $\mathrm{U}$ & $\begin{array}{c}\text { Ratio } \\
\mathrm{A}+\mathrm{U} / \mathrm{G}+\mathrm{C}\end{array}$ \\
\hline Control (saline) & 22.2 & 23.7 & 29.0 & 25.2 & 0.955 \\
\hline Fraction $3(5 \mathrm{mg})$ & 22.1 & 23.4 & 28.9 & 25.6 & 0.960 \\
\hline Ribosomal RNA ${ }^{a}$ ) & 29.1 & 18.6 & 31.9 & 20.4 & 0.62 \\
\hline Rat liver $\mathrm{DNA}^{b}$ & 21.5 & 28.7 & 21.4 & $28.4(\mathrm{~T})$ & 1.33 \\
\hline
\end{tabular}

The values are the averages of duplicate determinations on two groups of 3 rats. Variation between groups was about $\pm 0.5 \%$.

a) Taken from S. Osawa, Biochim. Biophys. Acta, 42, 244 (1960).

b) Taken from G.P. Georgiev and V.L. Mantieva, Biochim. Biophys. Acta, 61, 153 (1962).

The base ratios of ${ }^{32} \mathrm{P}$ pulse-labeled interphase nuclear RNA are indicated in Table IV. The base composition of the rapidly labeled interphase RNA is distinguished from that of ribosomal RNA, and interphase nuclear RNA is richer in the proportion of adenine and uridine nucleotide than is the ribosomal RNA. Also, interphase RNA did not correspond to liver DNA base ratio with uracil replacing thymine nucleotide and ratio $A+U / G+C$ showed the value of intermediate between ribosomal and DNA-like RNA.

\section{Discussion}

We have described the synthesis and characterization of liver nuclear RNA and interphase RNA induced by fraction 3 or 4 isolated from ginsenh roots.

18) A. Sibatani, S.R. deKolet, V.G. Allfrey, and A.E. Mirsky, Proc. Natl. Acad. Sci. U.S., 48, 471 (1962).

19) S. Hiai, H. Seno, and H. Oura, unpublished observation. 
Hydrocortisone administration to adrenalectomized rats increases the rate of synthesis of nuclear RNA, the effect of which becomes remarkable after about $60 \mathrm{~min}$ and increases to about 3 -fold by $4 \mathrm{hr}$, as measured by pulse-labeling technique. The rapid rise in the rate of nuclear RNA synthesis after $60 \mathrm{~min}$ is accompanied by a gradual accumulation of the induced tryptophan pyrrolase and tryosine- $\alpha$-ketoglutarate transaminase. ${ }^{17,20)}$

The effect of ginseng extract on the incorporation rate of labeled precursor into nuclear RNA similarly showed a maximum increase at $4 \mathrm{hr}$ after intraperitoneal administration to rats (Fig. 1), but $5-10 \mathrm{mg}$ of fraction 3 or 4 showed no increase of these hepatic enzyme activities at $6 \mathrm{hr}$ after treatment. 21 ) On the other hand, the administration of Celite, a nonspecific metabolism stressing agent, induced a marked increase of these enzyme activities. ${ }^{22}$ These experimental results suggest that the action of ginseng extract is not to stressing the animals to increase the secretion of steroid hormones.

Loeb and Gelboin ${ }^{14)}$ reported that methylcholanthrene-induced rat liver caused an increase in the uptake of orotic acid into nuclear RNA which suggests increased RNA synthesis, and the RNA content of isolated nuclei at $4 \mathrm{hr}$ after treatment is almost the same as in the control animals. However, at $16 \mathrm{hr}$ after treatment, there is a significant increase $(15-50 \%)$ in nuclear RNA content of the isolated nuclei as shown by an increase in the ratio of RNA to DNA.

In the present experiments, the RNA to DNA ratio of nuclei isolated at each interval after administration of fraction 3 was almost the same as in the control.

In order to study the effect of ginseng extract on the DNA synthesis, we assayed the incorporation rate of ${ }^{3} \mathrm{H}$-thymidine into liver nuclear DNA at $14 \mathrm{hr}$ (labeling time, $4 \mathrm{hr}$ ) and at $18 \mathrm{hr}$ (labeling time, $18 \mathrm{hr}$ ) after in vivo administration of $5 \mathrm{mg}$ of fraction 3 , but rates of DNA synthesis of treated rats were not different from that of DNA synthesis in normal liver (Table I and V).

TABLE V. Effect of Fraction 3 on the Incorporation of ${ }^{3} \mathrm{H}$-Thymidine into Liver Nuclear DNA

\begin{tabular}{clclllr}
\hline \hline $\begin{array}{l}\text { Expt. } \\
\text { No. }\end{array}$ & Material & $\begin{array}{l}\text { Period after } \\
\text { fraction 3 } \\
\text { treatment } \\
\text { (hr) }\end{array}$ & $\begin{array}{l}\text { Period after } \\
\text { isotope } \\
\text { injection } \\
\text { (hr) }\end{array}$ & $\begin{array}{l}\text { No. of } \\
\text { rats }\end{array}$ & $\begin{array}{l}{ }^{3} \text { H-Thymidine } \\
\text { (cpm/mg } \\
\text { nuclear DNA) }\end{array}$ & $\%$ \\
\hline 1 & control (saline) & 14 & 4 & 3 & 92 & 100 \\
2 & fraction 3 & 14 & 4 & 3 & 87 & 95 \\
& control (saline) & 18 & 18 & 3 & 120 & 100 \\
fraction 3 & 18 & 18 & 3 & 108 & 90 \\
\hline
\end{tabular}

Expt. 1: At $10 \mathrm{hr}$ after the first administration of fraction $3(5 \mathrm{mg})$, fraction $3(5 \mathrm{mg})$ and ${ }^{2} \mathrm{H}$-thymidine $(20$ $\mu \mathrm{Ci} / \mathrm{rat}$ ) were simultaneously injected intraperitoneally to animals. Four hr later animals were killed by decapitation. DNA was assayed by the Burton method.

Expt. 2: At $18 \mathrm{hr}$ after simultaneous intraperitoneal administration of fraction $3(5 \mathrm{mg})$ and ${ }^{2} \mathrm{H}$-thymidine $(20 \mu \mathrm{Ci} / \mathrm{rat})$ and the second administration of fraction $3(5 \mathrm{mg})$ was carried out $4 \mathrm{hr}$ prior to killing by decapitation.

From the experiments of utilizing labeled orotic acid and ${ }^{32} \mathrm{P}$-ortho-phosphate with the labeling period of $20 \mathrm{~min}$ and $60 \mathrm{~min}$, respectivity, we observed almost the same increasing rates in the specific radioactivity of nuclear RNA at $4 \mathrm{hr}$ after administration of fraction 3 or 4 (Fig. 1, Table II, and III). Also, the dose-response curve of actinomycin-D on the fraction 3-stimulated nuclear RNA incorporation showed that the suppressed rate of ${ }^{3} \mathrm{H}$ orotic acid incorporation into nuclear RNA is almost parallel with that of the control animals

20) L.D. Garren, R.R. Howell, G.M. Tomkins, and R.M. Crocco, Proc. Natl. Acad. Sci. U.S., 52, 1121 (1964).

21) H. Oura, S. Nakashima, K. Tsukada, and Y. Ota, Chem. Pharm. Bull. (Tokyo), to be published.

22) F.T. Kenney and R.M. Flora, J. Biol. Chem., 236, 2699 (1961). 
(Fig. 2). In a previous paper, ${ }^{3}$, we reported that the increase specific radioactivity of the liver RNA is not due to the change in the pool size of endogenous acid-soluble nucleotides.

These observations seem to suggest that the nuclear RNA increased by treatment with fraction 3 or 4 is transferred rapidly to the cytolplasm without accumulating in the nucleus, and the increased specific activity of the nuclear RNA by ginseng extract show an increase of RNA synthesis in the nucleus. This assumption was also supported by the increase of RNA polymerase activity in liver nuclei, ${ }^{23)}$ of heavy polysomes content in the postmitochondrial supernatant, and of incorporation rate of labeled precursor into polysomal RNA of the cytoplasm from fraction 3 or 4 -induced liver. ${ }^{24)}$

In the experiments on hydrocortisone, ${ }^{25)}$ growth hormone, ${ }^{26)}$ and testosterone ${ }^{27}{ }^{28}$ ) the sedimentation distribution and base composition of the induced nuclear RNA are indistinguishable from those of RNA that are pulse-labeled in the absence of hormone. It was found from the sedimentation profile observed in this study (Fig. 3B) that the stimulatory effect of ginseng extract orotic acid incorporation was different in various RNA fraction, and that it was largest in the $10 \mathrm{~S}$ region. Also, the base composition of the interphase RNA from fraction 3-induced liver showed a value intermediate between that of ribosomal and DNAlike RNA, and the fraction 3 stimulates the synthesis of both the ribosomal RNA precursor and the DNA-like RNA without a selective effect on one of these in a nucleus. From the sedimentation profile by sucrose density gradient of labeled polysomal RNA from fraction 4 -induced liver, we observed increased rates of labeled precursor into ribosomal 29S, 18S, and m-RNA of the cytoplasm. ${ }^{\mathbf{2 4})}$ These experimental results suggest that the stimulation of nuclear RNA synthesis by fraction 3 or 4 may be accompanied by an acceleration of ribosomal RNAs and m-RNA as well as that by many hormones. $\left.{ }^{4}\right)$

On the basis of the present evidence, it seem that the ginseng extract significantly enhances nuclear RNA synthesis, and as its results it would seem to stimulate protein synthesis in the cytoplasm. It was found that the DNA-dependent RNA polymerase activity was stimulated by administration of ginseng extract in vivo in assay as an "aggregate" enzyme of rat liver nuclei as describes in a paper of this series. ${ }^{23)}$ Therefore, the ginseng extract may be expected to have a metabolic stimulating or hormone-like action which occurs at the level of transcription on DNA of liver chromatin by direct or indirect action.

Acknowledgement The authors are indebted to Mr. Y. Hirai for technical assistance.

23) S. Hiai, H. Oura, K. Tsukada, and Y. Hirai, Chem. Pharm. Bull. (Tokyo), 19, 1656 (1971).

24) H. Oura, K. Tsukada, and H. Nakagawa, Chem. Pharm. Bull. (Tokyo), to de published.

25) D.L. Greeman, W.D. Wicks, and F.T. Kenney, J. Biol. Chem., 240, 4420 (1965).

26) A. Korner, Biochem. J., 92, 449 (1964).

27) W.D. Wicks and F.T. Kenney, Science, 144, 1346 (1964).

28) S. Liao, J. Biol. Chem., 240, 1236 (1965). 